•保护论坛・

\title{
救救北京的睡菜
}

\author{
刘华杰* \\ (北京大学哲学系, 北京 100871)
}

\section{Save Menyanthes trifoliata in Beijing}

Huajie Liu*

Department of Philosophy, Peking University, Beijing 100871

北京延庆田宋营生长着一种美丽的水生植物 睡菜(Menyanthes trifoliata)。它在此生长了多久, 没人知道, 恐怕早于任何一个北京人。《北京植物 志》甚至也未能收录它。2009 年 4 月林秦文告诉我: 田宋营有睡菜! 我立即驾车前往观看。它美极了! 三言两语无法描述, 植物志上的官样描写不足以展 现它的鬼力。

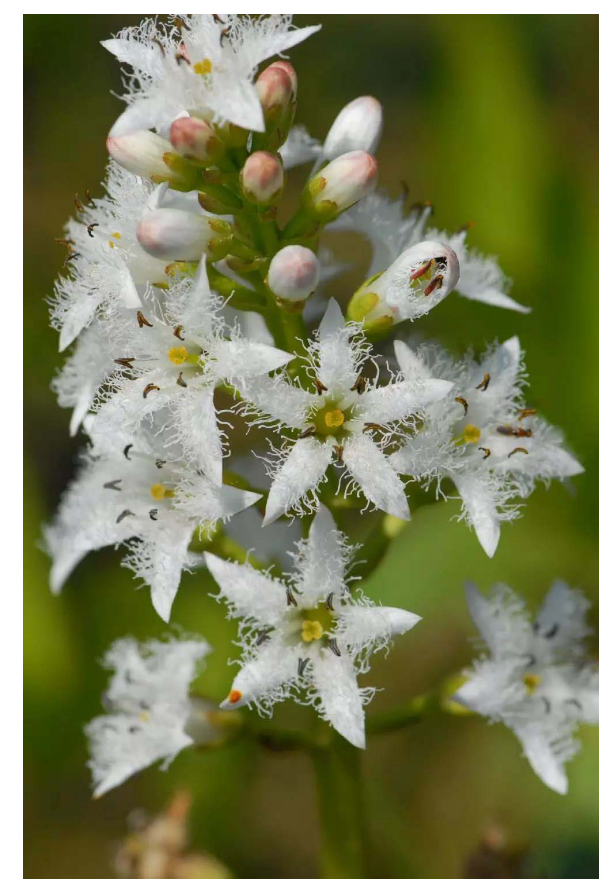

自那以后，每年 4 月我都会过去欣赏。直到有 一年, 原来上万株的睡菜突然不见了! 2017 年和 2018 年在田宋营都没有找到。为何? 明显是人为破
坏。当然, 不是有意破坏, 是为了硬化道路, 整治平 行于大秦铁路的一条多半只有一米多宽的小水渠 蔡家河, 挖泥机把睡菜生活环境毁坏了! 目前蔡家 河中花萄 (Butomus umbellatus)、水芹 (Oenanthe javanica)、毒芹(Cicuta virosa)、泽芹(Sium suave)、 野慈姑(Sagittaria trifolia)、盒子草(Actinostemma tenerum)、欧地笋(Lycopus europaeus)、赤麻(Boehmeria silvestrii)、黑三棱(Sparganium stoloniferum)、 槐叶苹(Salvinia natans)等本土植物仍然完好, 为何 单独缺了睡菜? 可能因为睡菜的根状茎粗大(直径 1-3 cm, 长 100-250 cm), 经不起挖泥机的扰动吧。

在那里, 现在不见睡菜的芳踪, 却发现了葫芦 科著名入侵植物刺果瓜(Sicyos angulatus)。科学界对 北京睡菜缺少足够的关注度, 文献较少提到它。分 布地一般会提到田宋营(张曲雨等, 2007)、张山营以 及野鸭湖湿地(徐景先等, 2009; 赵锋等, 2015; 刘冰 等, 2018), 都是指北京延庆妫河的支流蔡家河及附近 不算大的一个区域。另外也有人在北京怀柔见到过, 未证实。可以肯定的是, 在北京睡菜数量非常少。

睡菜彻底地告别了延庆、告别了北京?

睡菜的消逝, 在北京意味着一个科的植物的消 失。睡菜科在北京只有这一个种。想一想, 它未曾进 入修订版的《北京植物志》就永别了, 真的很可惜。

明年, 北京延庆将举办声势浩大的“2019 中国 北京世界园艺博览会”, 世界的目光将聚焦到延庆。 延庆、北京乃至于整个中国为此都做出了巨大努力, 
大兴土木, 投资数十亿甚至百亿。世园会场馆坐落 于延庆妫水河畔, 而那美丽的睡菜就在它的正北方 不远处, 距此不过 $8 \mathrm{~km}$ !

中国举办了一届又一届世园会, 回想一下, 保 护了哪些本土物种? 展示了什么本土物种? 没有野 生植物作基础，园艺植物能走多远?

听说蔡书记为了这届世园会, 已三次考察延庆, 亲临现场指导工作。在此, 我作为中国野生植物保 护协会一位理事、北京市一名公民, 特意向书记呼 吁: 请借世界园艺博览会之机, 救救北京的睡菜! 几乎不用特别花费, 您只要提醒有关部门关注睡菜, 不要再折腾田宋营的那道小沟渠, 它或许就会再长 起来, 每年如期开出美丽的花朵。您也可以把它作 为一个案例: 将延庆的睡菜在北京世园会上展示出 来, 提醒更多的北京人认识乡土植物, 欣赏它们、保 护它们。睡菜在生物多样性保护上的意义, 不亚于 北京市重点保护野生植物名录中一级保护植物大 花杓兰(Cypripedium macranthum)、刺楸(Kalopanax septemlobus)、轮叶贝母(Fritillaria maximowiczii)等。

北京能否容得下本土野花睡菜, 相比首都北京 众多大事或许微不足道, 但换个角度看, 它也是检 验“绿色北京”、生态北京的一个指标。

关于睡菜的濒危程度和保护地位, 还可以多说 几句。就全国或全世界范围看, 睡菜并不是焦点物 种, 它在内蒙古、吉林、云南、四川等地都有分布。 它的地位大约相当于花萄科的花﨎和水鳖科的龙 舌草(Ottelia alismoides), 它们在北京之外许多地方 都有分布。但是, 即使睡菜看起来不够美、分类学 上也不够特别(在 APG 系统中睡菜从龙胆科中独立 出来, 列于睡菜科。睡菜的消失, 意味着北京人没 有眼福欣赏一整个植物科的风采, 对分类学教学显 然有影响), 它也有生存的权利, 是生态系统的一个 必要组分。保护等级是根据许多人为指标建构出来 的, 我们有充分的理由认为睡菜在北京是值得重点 保护的对象。从利奥波德(Aldo Leopold)的生态学 (包括了经济上、美学上和伦理上的综合考虑)角度 看, 睡菜作为本土物种, 它的存在与否影响着首都 北京生态的整体性、稳定性和美丽(integrity, stability, and beauty)程度。缺了睡菜的北京湿地是不完整的。 田宋营一带湿地被大范围“整治” (修路、填埋、垦
植作物、栽种经济林)破坏了局部生态系统, 现在发 现睡菜被有意无意整治了，下一个可能就是花萄、 菰(Zizania latifolia)或者水鳖(Hydrocharis dubia)。

目前田宋营一带的蔡家河水质尚好, 建议在此 重新引种睡菜。北京城区的奥林匹克森林公园湿地 中有一些浅水区, 也适合引种睡菜。

其实, 本土平凡植物被忽视是一个老问题。之 所以现在重提, 很大程度上是考虑到在田宋营不远 处将举办由副总理胡春华任主任, 多部门官员出任 副主任的 2019 中国北京世界园艺博览会。考验北 京的时候到了。睡菜问题摆在这里, 呼吁引起重视。

青海然果村的甘蒙柽柳(Tamarix austromongolica)因修水库面临被淹, 引起社会广泛关注。两 年后的 2018 年 8 月有了新消息: 水库照建, 拟对淹 没区甘蒙柽柳迁地保护。都怪它还不够特别！如未 列入《中国珍稀濒危保护植物名录》和《国家重点 保护野生植物名录》，不属于珍稀濒危树种和国家 级、省级重点保护树种。但是人们同时又感到它们 确实非常特别。大树能移植成活吗? 似乎“青山”终 究比不过“金山”。学界、政府是否要更新保护理念 和保护政策?

\section{参考文献}

Liu B, Lin QW, Li M (2018) Field Guide to Wild Plants of China (Vol. Beijing), pp. 270-271. The Commercial Press. (in Chinese) [刘冰, 林秦文, 李敏 (2018) 中国常见植物 野外识别手册(北京册), 270-271页. 商务印书馆, 北京.]

Xu JX, Zhao LC, Lin QW (2009) Wetland Plants in Beijing, pp. 12, 117. Bejing Science and Technology Press, Beijing. (in Chinese) [徐景先, 赵良成, 林秦文 (2009) 北京湿地 植物, 12页, 117页. 北京科学技术出版社, 北京.]

Zhang QY, Hu D, Du PZ (2008) New record plants from wetland in Beijing. Journal of Capital Normal University (Natural Science Edition), 29(3), 56-59, 63. (in Chinese with English abstract) [张曲雨, 胡东, 杜鹏志 (2008) 北 京地区湿地植物新记录. 首都师范大学学报(自然科学 版), 29(3), 56-59, 63.]

Zhao F, Hu RY, Du SL, Shi XF, Li XD (2015) Rapid propagation of Menyanthes trifoliata L. in vitro. Acta Botanica Boreali-Occidentalia Sinica, 35, 410-415. (in Chinese with English abstract) [赵峰, 胡若洋, 杜思乐, 石 雪飞, 李学东 (2015) 睡菜离体快繁技术的研究. 西北植 物学报, 33, 410-415.]

(责任编辑：黄祥忠) 